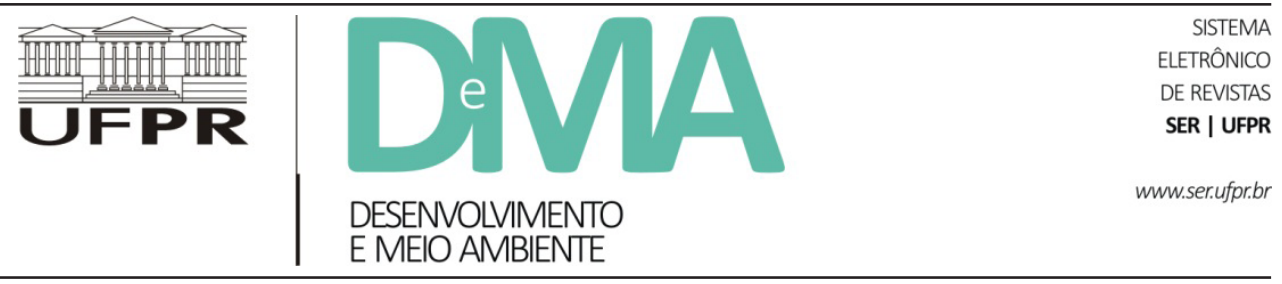

\title{
A vulnerabilidade social em tempos de acumulação flexível: uma contribuição para o debate no campo socioambiental
}

\section{Social Vulnerability in Flexible Accumulation Times: A Contribution to the Debate in the Environmental Field}

\author{
Natália Tavares AZEVEDO ${ }^{{ }^{*}}$ \\ ${ }^{1}$ Universidade Federal do Paraná (UFPR), Curitiba, PR, Brasil. \\ *E-mail de contato: natytav@yahoo.com.br
}

Artigo recebido em 8 de fevereiro de 2016, versão final aceita em 25 de julho de 2016.

RESUMO: $\quad$ A noção de vulnerabilidade tem sido utilizada em diversos campos do conhecimento. Um de seus usos se faz nas pesquisas interdisciplinares sobre a vulnerabilidade socioambiental, que é entendida de forma simplificada como a sobreposição de situações de vulnerabilidade social e riscos ambientais. Identificou-se que o debate, no campo ambiental, tem sido dominado por perspectivas das ciências sociais de caráter individualista e funcionalista, com pouca abertura para leituras críticas. De forma a contribuir para a ampliação desse debate, busca-se nesse artigo apresentar uma discussão teórica acerca da noção de vulnerabilidade social. Argumenta-se que, em que pese ser utilizada por distintas vertentes e orientações teóricas e ideo-políticas, seu uso dominante se estabeleceu dentro do pensamento liberal revisitado. Essa hegemonia está em consonância com as transformações societárias ocorridas desde a década de 1970, com a crise do regime de acumulação fordista e a emergência do regime de acumulação flexível. Neste, uma nova gramática social para tratar dos temas relativos à pobreza, à desigualdade e à injustiça social toma forma, na qual se destaca uma abordagem da vulnerabilidade baseada nos ativos e nas capacidades, focada nos indivíduos e nas suas carências, respondendo a demandas de ajuste fiscal do Estado e corte nos gastos públicos. Como alternativa, dá-se ênfase a uma abordagem processual, focada nos direitos e na proteção e na exposição desigual aos riscos e suas causas econômicas e políticas.

Palavras-chave: vulnerabilidade social; vulnerabilidade socioambiental; questão social; pobreza; direitos.

ABSTRACT: The notion of vulnerability has been used in various fields of knowledge. One of its uses is in interdisciplinary research on environmental vulnerability, in which is understood in a simplified way as the overlap of social vulnerability and environmental risks. The debate in the environmental field was identified as having been dominated by perspectives of social science individualistic character and functionalist, with little openness for critical readings. In order to contribute to the expansion of this debate, we seek in this paper to present a theoretical discussion about the notion of social vulnerability. It is argued that, despite being used by authors from different theoretical and ideal political orientations, its dominant use is established within the revisited liberal thought. This hegemony is in line with the societal changes occurring since the 1970s, with the crisis of 
the Fordist regime of accumulation and the emergence of flexible accumulation regime. A new social grammar takes shape to address issues related to poverty, inequality and social injustice, which stresses an approach to vulnerability based on the assets and the capabilities, focused on individuals and their needs, responding to fiscal adjustment and cutting public spending. Alternatively, emphasis is given to a processual approach, focused on the rights and protection and on the unequal exposure to risk and its economic and political causes.

Keywords: social vulnerability; social-environmental vulnerability; social question; poverty; rights.

\section{Introdução}

Nesse artigo, versa-se sobre uma noção que tem sido amplamente utilizada nos meios acadêmicos, nas agências governamentais e nos think tanks na atualidade - a noção de vulnerabilidade social. Essa reflexão se faz em um contexto específico, que delimita e orienta o caminho adotado para tanto. Trata-se de reflexões teóricas que visam balizar a pesquisa e a análise sobre a situação de vulnerabilidade socioambiental à luz do debate sobre justiça ambiental (Acserald et al., 2009). Considerando-se que a vulnerabilidade socioambiental é entendida, de forma simplificada, como a sobreposição de situações de vulnerabilidade social e riscos ambientais ${ }^{1}$ (Alves, 2006), compreender de forma mais aprofundada essas categorias é exercício necessário para o desenvolvimento de pesquisas mais consistentes.

O contato com a temática que motivou esta reflexão teve origem principalmente na literatura das ciências ambientais preocupadas com as mudanças ambientais globais, ou seja, num contexto específico e se apoiando em determinadas correntes das ciências sociais que têm ocupado um papel mais preponderante no diálogo que constrói as ciências ambientais como campo de conhecimento interdisciplinar. Uma revisão mais aprofundada sobre a temática da vulnerabilidade socioambiental indicou que, embora existam distintas correntes com usos diferenciados da noção, a leitura do mundo social predominante se assenta em abordagens individualizantes ${ }^{2}$. Assim, percebeu-se que a noção - desde a perspectiva da sociedade, tal qual utilizada de forma mais ampla nas ciências ambientais (especialmente na environmental change science) - é oriunda de interpretações de correntes ligadas ao individualismo metodológico e ao funcionalismo (Castree et al., 2014), mas com pouca frequência as fontes da leitura do mundo social são explicitadas e problematizadas e há pouca abertura para abordagens alternativas. Como destacou Acselrad (2013), o ambiente do conhecimento do debate ambiental, especialmente desde os anos 2000, tem se mostrado pouco propício ao exercício da reflexão e da capacidade de crítica.

Esse cenário conduziu a busca da compreensão dos sentidos do termo vulnerabilidade social no campo da chamada questão social, que inclui tanto as agências científicas quanto as políticas e governamentais. Não se trata de catalogar suas diferentes definições e usos, mas compreender o sentido dominante atual dado ao debate sobre a questão social a partir da qual é incorporada pelas ciências ambientais. Salienta-se aqui que se parte

\footnotetext{
${ }^{1}$ A problematização da noção de risco e os debates teóricos em torno dela estão fora do escopo desse artigo, embora reconheçamos a inter-relação entre os dois campos, particularmente no debate nas ciências ambientais. Seu uso se dá sempre de forma genérica ao longo do texto.

2 Para uma visão dos usos da noção de vulnerabilidade na relação sociedade-ambiente, ver, entre outros: Turner, 2003; O’brien et al., 2004; Marandola \& Hogan, 2006; Adger, 2006; Cutter et al., 2009; Cutter, 2011; Alwang et al., 2011; Porto, 2011.
} 
do entendimento de que essas concepções são internalizadas no debate sobre vulnerabilidade socioambiental, porém poucas vezes problematizadas. Elas se expressam em noções como susceptibilidade ao dano, falta de capacidade de adaptação, tal qual na definição bastante difundida oferecida por Adger (2006, p. 268), que caracteriza a vulnerabilidade como o "estado de susceptibilidade a danos causados por exposição a tensões/estresses associados com a mudança ambiental e social e a ausência de capacidade de adaptação". Essa susceptibilidade pode se expressar tanto nos sistemas naturais quanto nos sistemas sociais (ou em ambos ao mesmo tempo) e a crítica aqui ofertada se dirige à forma de conceber essa noção em relação à sociedade.

Como resultado dessa investigação teórica, construiu-se o argumento central do texto. Busca-se demonstrar que a noção de vulnerabilidade social assumiu uma forma dominante, de caráter liberal, funcionalizada para lidar com a questão social a partir da constituição de um novo regime de acumulação de capital, usando os termos de David Harvey (2002) - que, por sua vez, se vale da Escola da Regulação de Allan Lipietz e outros -, a acumulação flexível, que responde pelo desmonte do Estado de Bem-Estar Social e do regime de acumulação keynesiano-fordista, com a adoção de reformas neoliberais e uma forma distinta de administração da questão social.

Isso porque, segundo Harvey (2002), um regime de acumulação descreve a estabilização, por um longo período, da alocação do produto líquido entre consumo e acumulação. Isso implica em certa correspondência entre a transformação tanto das condições de produção como das condições de reprodução dos assalariados. O problema, como aponta Harvey, é fazer os comportamentos de todo tipo de indivíduos - capitalistas, trabalhadores, funcionários públicos, financistas e todas as outras espécies de agentes político-econômicos - assumirem certa modalidade que mantenha o regime de acumulação funcionando. Isso demanda uma materialização do regime de acumulação, que toma a forma de normas, hábitos, leis, redes de regulamentação, etc., que dão unidade ao processo e garantem a consistência apropriada entre comportamentos individuais e o esquema de reprodução.

Sendo assim, e ainda conforme Harvey (2002), existem duas áreas de dificuldade para manter a viabilidade do sistema econômico capitalista: a primeira advinda das qualidades anárquicas dos mercados de fixação de preços e a segunda derivada da necessidade de exercer suficiente controle sobre o emprego da força de trabalho para garantir a adição de valor à produção. No que diz respeito a essa última dificuldade, entre todos os problemas da organização da força de trabalho, demanda-se também uma forma de lidar com a população que não encontra ocupação ativa dentro do mercado de trabalho formal (superpopulação relativa, nos termos de Marx), ou seja, com as expressões do que se convencionou chamar questão social - pobreza, desemprego, fome, etc.

O campo científico participa ativamente da produção das formas de legitimação - e também de contestação - dos regimes de acumulação em sua totalidade, com suas complexas inter-relações, hábitos, práticas políticas e formas culturais. Nesse sentido, entende-se essa transformação nas abordagens teóricas e metodológicas da questão social a partir da proposição de Meszáros (2009), de que as fases particulares do desenvolvimento socioeconômico são marcadas por significativas inovações teóricas e metodológicas, de acordo com as circunstâncias em modificação. Essas mudanças metodológicas e transformações teóricas se acomodam em relação aos limites restritivos da moldura estrutural comum que define a época em sua totalidade. 
Nesse sentido, o social, como objeto de estudo e de intervenção, passou por profundas transformações desde sua emergência no século XIX e no percurso do século XX, alvo de disputas teóricas, políticas e simbólicas. Enquanto objeto de estudo científico, é reivindicado por distintas tradições teóricas, que o concebem de maneira diferenciada e que implicam em projetos societários distintos (Netto, 2007) e, portanto, diferentes modos de operacionalizar tanto as formas de conhecer a concretude do mundo social quanto de implementar políticas e ações sobre estas realidades.

Com a crise do capital na década de 1970, a decadência da sociedade salarial e securitária, uma nova gramática social entra em voga, para atender as demandas sociais distributivas de forma focalizada nos segmentos mais vulneráveis da população, ao invés do estabelecimento de políticas universalizantes baseadas na seguridade social ampliada. É nesse escopo que a noção de vulnerabilidade ganha abrangência. Não se pretende dizer, porém, que o uso liberal da noção de vulnerabilidade é o único feito na literatura. Deseja-se apenas apontar alguns sentidos dominantes que foram se configurando em seu uso. Dessa forma, busca-se, ao final do texto, habilitar a noção para o exercício crítico, enfocando seu caráter processual e relacional, como tem apontado Acselrad $(2013 ; 2015)$ e associando-a ao enfoque dos direitos, como aponta Dean (2009). Salienta-se aqui, uma vez mais, que o artigo pretende ser uma contribuição ao debate no campo socioambiental, na medida em que problematiza a visão social que está por trás dos usos mais correntes nas ciências ambientais, porém situando o debate na questão social.

\section{A questão social: breve trajetória histórica e teórica}

\subsection{O surgimento da questão social e o capitalismo liberal ${ }^{3}$}

Segundo Netto (2003), todas as referências possíveis sugerem que a expressão questão social foi empregada pela primeira vez por volta de 1830, para dar conta do fenômeno mais evidente da história da Europa Ocidental que experimentava os impactos da primeira onda industrializante iniciada na Inglaterra no último quarto do século XVIII - o pauperismo. A novidade da pauperização na instauração do capitalismo na sua fase liberal, reconhecida por pensadores de diferentes posições ideo-políticas, se constituía no crescimento da pobreza em razão direta com o aumento da capacidade social de produzir riquezas. A pobreza e a desigualdade nos períodos anteriores se davam num contexto social totalmente distinto, um quadro de escassez. Com o desenvolvimento das forças produtivas impulsionado pelo emergente capitalismo industrial, criaram-se condições objetivas para a redução ou mesmo para a superação da pobreza, mas, ao contrário, o que se registrou foi seu aumento paulatino pela expropriação dos camponeses do campo e pelo processo de urbanização.

Ainda como pontua Netto (2003), a designação da pauperização como questão social está diretamente ligada ao fato de que os pauperizados não se resignaram. Ao contrário, estes não se conformaram com sua situação, realizando protestos violentos e consolidando movimentos de trabalhadores, o que

\footnotetext{
A periodização feita aqui se concentra nos regimes de acumulação e nos seus modos de regulamentação, seguindo Harvey (2002), de forma a destacar o conjunto de ideias que pautam a interpretação e a intervenção sobre a questão social, sem deixar de reconhecer as polêmicas em torno das diferentes periodizações do capitalismo.
} 
representava uma ameaça às instituições sociais existentes e à manutenção da nova ordem social burguesa. É a partir da perspectiva de subversão dessa nova ordem, portanto, que o pauperismo se vai designar como questão social. Segundo o autor, a noção se consolida dentro do espectro sociopolítico no vocabulário do pensamento conservador. Segundo Montaño (2012), a expressão questão social começou a ser empregada maciçamente a partir da separação positivista entre o econômico e o social. É o período que marca o surgimento da análise do social com pretensões científicas, com a emergência da sociologia, da psicologia e de outras ciências sociais.

Dessa forma, o social poderia ser visto como fato social e como um objeto científico diferenciável, que tinha como projeto político subjacente estabelecer uma nova ordem social para a emergente sociedade burguesa. Nessa leitura, via-se o social como algo natural, a-histórico, desarticulado dos fundamentos econômicos e políticos da sociedade, portanto, dos interesses e conflitos sociais. Assim, se o problema social (a "questão social") não tem fundamento estrutural, sua solução também não passaria pela transformação do sistema.

Como aponta Netto (2003), as manifestações imediatas da questão social - forte desigualdade, desemprego, fome, enfermidades, penúria, desamparo frente a conjunturas econômicas adversas - são vistas, no pensamento conservador, como desdobramento, na sociedade moderna, de características inelimináveis de toda e qualquer ordem social, que podem ser objeto de intervenção política limitada (preferencialmente com suporte científico). Assim, no período do capitalismo liberal, que vai de seu surgimento embrionário no século XVI até meados do início do século XX, pobreza, miséria e suas formas de manifestação não eram entendidas, no pensamento dominante à época, como resultado de exploração econômica, mas como fenômenos autônomos e de responsabilidade individual ou coletiva dos setores por ela atingidos. A questão social é separada dos seus fundamentos econômicos (a contradição capital/trabalho, baseada na relação de exploração do trabalho pelo capital, que encontra na indústria moderna seu ápice) e políticos (as lutas de classes e sua expressão em torno da ação do Estado). É considerada, sob a perspectiva funcionalista, como problema social, cujas causas estariam vinculadas a questões culturais, morais e comportamentais, demandando ações para garantir a coesão social. O enfrentamento, seja a pobreza considerada como carência ou déficit (onde a resposta viria de ações filantrópicas e de beneficência social), ou entendida como mendicância e vadiagem (onde a resposta é a criminalização da pobreza, enfrentada com repressão/reclusão) remete, via de regra, à consideração de que as causas da questão social e da pobreza encontram-se no próprio indivíduo (ou, em uma cultura da pobreza, nos aspectos morais), e em uma intervenção psicologizante, moralizadora e contenedora desses indivíduos (Montaño, 2012).

Como pontuam Behring \& Boschetti (2009), as ideias e os valores liberais que sustentaram a atuação do emergente Estado capitalista, no século XIX, após a Revolução Industrial, colocavam o livre mercado como o melhor regulador social e produtor do bem comum, decorrendo assim a não intervenção estatal e a negação das políticas sociais. Como a visão da pobreza apontava para aspectos morais dos indivíduos, as ações estatais sobre a questão social deveriam ser apenas paliativas, para atender crianças, idosos e deficientes, e sustentadas basicamente pela caridade privada, ou ainda, higienistas e repressivas.

É somente com a luta dos trabalhadores pela conquista de direitos civis e políticos que, gradualmente e de forma diferenciada entre os países, vão 
surgindo as políticas sociais, dependendo igualmente do grau de desenvolvimento das forças produtivas e da correlação de forças entre as classes sociais que se expressam no âmbito do Estado. Marca desses processos é a criação de seguros sociais em diferentes países da Europa, ainda no século XIX. Uma inflexão significativa na concepção liberal do Estado, contudo, só irá ocorrer com a crise do capital a partir de 1929 (Behring \& Boschetti, 2009).

\subsection{O regime keynesiano-fordista e o bem-estar social}

Segundo Montaño (2012), na fase do capitalismo monopolista do pós-Segunda Guerra Mundial, período da expansão produtiva fordista e marcado pela organização e pela luta dos trabalhadores, bem como pela Guerra Fria e a disputa entre socialistas e capitalistas, desenvolve-se uma nova estratégia hegemônica do capital que incorpora a classe trabalhadora urbano-industrial. Nesse novo período, como coloca Harvey (2002), apresentava-se não somente um novo modo de produção de massa, mas também de consumo de massa, um novo sistema de reprodução da força de trabalho, uma nova política de controle e gerência do trabalho, uma nova estética e uma nova psicologia, em suma, um novo tipo de sociedade democrática, racionalizada, modernista e populista. A consolidação desse período dependeu de um processo de intervenção ativa do Estado na economia e no conjunto da vida social, que só vai se efetivar de forma abrangente no período pós-guerra. Corporações, Estado e sindicatos (controlados para expurgar forças radicais, como salienta Harvey, 2002) garantem a estabilidade do sistema de regulação do período, em que pese diferenças na forma de relação entre estes atores em diferentes países, no centro e na periferia do sistema.
Com o regime de acumulação keynesiano-fordista, pobreza e miséria, expressões da questão social, são vistas a partir das formulações keynesianas como um problema de distribuição do mercado, como um descompasso na relação oferta/demanda de bens e serviços. Como explicita Montaño (2012), o problema de distribuição estaria relacionado ao déficit de demanda efetiva, criado pela sobreoferta de força de trabalho não absorvida pela esfera produtiva. Com o desenvolvimento das forças produtivas (ou, segundo a interpretação keynesiana, em função do ainda insuficiente desenvolvimento), um contingente da população fica excluído do mercado de trabalho e, ao não poder vender sua força de trabalho, não tem fonte de renda que lhe permita adquirir no mercado bens e serviços. Ainda segundo Montaño (2012), para enfrentar esse hiato, de acordo com Keynes, o Estado deve passar a intervir em dois sentidos: (a) responder a algumas necessidades (carências)/ demandas dessa população; (b) criar as condições para a produção e o consumo, incentivando uma contenção do desemprego ou uma transferência de renda (seguridade social e políticas sociais). Promove-se o chamado "círculo virtuoso" fordista-keynesiano.

Para Montaño (2012), esta abordagem avança ao considerar as manifestações da questão social como um produto (transitório) do sistema capitalista. Apesar disso, tal concepção ainda conserva o tratamento segmentado das manifestações da questão social, tal como no pensamento liberal clássico. Destaca que, nessa abordagem, considera-se a pobreza como um problema de distribuição. Com isso, sua gênese é deslocada da esfera econômica, do espaço da produção, da contradição entre capital e trabalho, para a esfera política, no âmbito da distribuição, como uma questão entre cidadãos carentes e o Estado. Assim, o tratamento da questão social e o combate à pobreza se delimitam a um processo de redistribuição. A questão social, assim, fica reduzida 
a garantia, mediante políticas e serviços sociais, ao acesso a bens e serviços por parte da população.

Cabe destacar, como salienta Netto (2003), que, nesse período "glorioso", experimentou-se um grande crescimento econômico, que permitiu aos países centrais do capitalismo a constituição de um Estado de Bem-Estar Social, fazendo com que a questão social e suas manifestações se tornassem um "privilégio" dos países do então chamado Terceiro Mundo. Dessa forma, a questão social se tornou um problema de subdesenvolvimento, entendido como uma situação transitória na esteira do crescimento e do progresso que todos os países deveriam experimentar (como no modelo de Rostow, 1961), se seguissem as fórmulas para tanto, ignorando as relações internacionais entre os países do centro e da periferia do sistema global do capital e da divisão internacional do trabalho. Os países então chamados subdesenvolvidos não chegaram a ter um Estado de Bem-Estar Social, ainda que medidas inspiradas nesses modelos tenham sido adotadas residualmente, como destaca Netto (2003).

Um ponto relevante na compreensão da questão social nas formulações teóricas que inspiraram o Estado de Bem-Estar é apontado por Vianna (2008). A autora, problematizando as relações entre igualdade x liberdade e universalização x focalização, indica que nas concepções de igualdade que subsidiaram o Estado de Bem-Estar prevalecia a concepção de resultados mais igualitários, em detrimento da versão de iguais oportunidades, própria do pensamento liberal. Por outro lado, no que diz respeito à liberdade, Vianna (2008) indica duas concepções - a primeira negativa, que a vê como ausência de restrições para o exercício do livre-arbítrio, enquanto a segunda tem como requisito a existência positivada de direitos substantivos e palpáveis, que exigem estruturas concretas (escolas, hospitais, etc.).
Em que pese as distintas configurações de modelos de Estado de Bem-Estar Social que se efetivaram, especialmente nos países centrais do capitalismo, como aponta a autora, com diferenciados imbricamentos entre liberdade e igualdade, a concepção que se firmou foi a de universalidade da política social. Esta, além da redução da pobreza, tinha em seu escopo a expansão da cidadania como conjunto de direitos acumulados historicamente civis, políticos e sociais.

Essa cidadania substantivada e ampliada, que se dá por meio de políticas sociais universalizadas, exige do Estado um papel robusto de produtor de bens e serviços para todos e aos quais todos têm direito - sistema de saúde e de educação públicos e universais, e também fortes investimentos para que todos possam gozar de benefícios como saneamento, moradia, transporte, etc. Essas concepções serão atacadas com a derrocada do regime keynesiano-fordista, a partir da década de 1970, com mudanças também nas formulações sobre a relação entre igualdade e liberdade, que se expressam por meio das políticas adotadas.

\section{O regime de acumulação flexível: a emergência da vulnerabilidade social diante dos ajustes neoliberais}

\subsection{A crise do regime keynesiano-fordista e a transição para a acumulação flexível}

Na década de 1970, a onda expansiva da dinâmica capitalista baseada no regime de acumulação keynesiano-fordista entrou em crise, colocando em xeque as conquistas da classe trabalhadora no Estado de Bem-Estar. Sem aprofundar excessivamente nas causas da crise que eclode em 1973 (que está fora do escopo desse artigo), salienta-se que, 
segundo Harvey (2002), já em meados da década de 1960 começam a surgir os primeiros sinais da crise, com o enfraquecimento da demanda efetiva nos Estados Unidos, compensada pela guerra à pobreza e pela guerra do Vietnã.

Segundo Harvey (2002), já havia indícios de problemas sérios no fordismo em meados dos anos 1960, no qual se combinaram uma série de elementos. Deu-se a recuperação da Europa Ocidental e do Japão, com a saturação de seu mercado interno e a demanda por criar novos mercados para exportação de seu excedente. A queda da produtividade e da lucratividade corporativas a partir de 1966 marcou o começo de um problema fiscal nos Estados Unidos, que só seria sanado às custas de uma aceleração da inflação, o que levou ao solapamento do papel do dólar como moeda-reserva internacional estável. Ainda segundo Harvey (2002), também nesse período ocorre a criação de políticas de substituição de importações em países do Terceiro Mundo, particularmente na América Latina, associadas a um grande movimento de multinacionais em direção à manufatura no estrangeiro, particularmente no sudeste asiático, gerando uma onda de industrialização fordista em ambientes inteiramente novos, nos quais os contratos sociais com o trabalho eram fracos ou desrespeitados. Disso resultaram o rompimento do acordo de Bretton Woods, a desvalorização do dólar e a instituição de taxas de câmbio flutuantes, muitas vezes voláteis, substituindo as taxas fixas da expansão pós-guerra. Capacidade de excedentes inutilizáveis e ociosos num ambiente de intensificação da competição, fundos excessivos e poucas áreas produtivas para investimento compunham o cenário da crise, gerando inflação e estagnação econômica, fazendo cair as taxas de lucro e provocando uma crise de acumulação.

Com o choque do petróleo em 1973 (aumento do preço definido pela OPEP e embargo ao ocidente por parte dos países árabes produtores de petróleo), ocorreu um grande impacto de deflação, tirando os países do mundo capitalista do torpor da estagflação e provocando uma onda de reformas que solaparam os compromissos fordistas, dando margem a um novo regime de acumulação, nomeado por Harvey (2002) de flexível.

A busca pela saída da crise e pela retomada das taxas de lucro engendrou novos e intensos processos de mudança societária. Como pontua Harvey (2002), a acumulação flexível é marcada por um confronto direto com a rigidez do fordismo. Apoia-se na flexibilidade dos processos e dos mercados de trabalho, dos produtos e padrões de consumo. Caracteriza-se pelo surgimento de setores de produção inteiramente novos, novas maneiras de fornecimento de serviços financeiros, novos mercados e, sobretudo, taxas altamente intensificadas de inovação comercial, tecnológica e organizacional. Ainda segundo Harvey (2002), esses poderes aumentados de flexibilidade e mobilidade permitem que os empregadores exerçam pressões mais fortes de controle do trabalho. Esse novo regime de acumulação flexível tem como base material, de acordo com Antunes (2002), o processo de reestruturação produtiva do capital e esta é a estrutura sobre a qual o projeto ideo-político neoliberal se erige.

Como destaca Netto (2012), os novos processos produtivos têm implicado uma extraordinária economia de trabalho vivo, elevando brutalmente a composição orgânica do capital, resultando num crescimento exponencial da força de trabalho excedentária em face dos interesses do capital, o exército industrial de reserva do capitalismo tardio. Ainda segundo Netto (2012), o chamado mercado de trabalho vem sendo radicalmente reestruturado - e todas as inovações levam à precarização das condições de vida da massa dos vendedores de força de trabalho: a ordem do capital é hoje, reconhecidamente, a ordem do desemprego e da informalidade. 
Como destaca Antunes (1998), mudanças tanto na materialidade quanto na subjetividade da classe trabalhadora decorreram dessa crise. Segundo o autor, há uma crescente redução do proletariado fabril, um incremento do subproletariado, resultante da precarização, com terceirizações, subcontratações, etc. Assim, a classe trabalhadora tornou-se mais heterogênea, mais fragmentada e mais complexificada, dividida entre trabalhadores qualificados e desqualificados, do mercado formal e informal, jovens e velhos, homens e mulheres, estáveis e precários, imigrantes e nacionais, etc., sem falar nas divisões que decorrem da inserção diferenciada dos países e de seus trabalhadores na nova divisão internacional do trabalho.

Essas transformações que vêm ocorrendo no sistema do capital desde a década de 1970 tiveram amplas repercussões na atuação dos Estados, com a disseminação da ideologia neoliberal e a apregoada redução da sua atuação, que deveria ser mais gerencial do que indutora. No que toca às exigências imediatas do grande capital, o projeto neoliberal restaurador viu-se resumido no tríplice mote da "flexibilização" (da produção, das relações de trabalho), da "desregulamentação" (das relações comerciais e dos circuitos financeiros) e da "privatização" (do patrimônio estatal) (Netto, 2012).

Nesse sentido, as políticas sociais passam a ser tensionadas e reduzidas, ao mesmo tempo pautadas por e abrindo espaço a visões diferenciadas sobre a atuação do Estado nesse aspecto. Ainda que a visão propriamente neoliberal, ou ultraliberal, de autores como Milton Friedman (1977), Friedrich Von Hayek (1983) ou Robert Nozick (1991), proponha total não intervenção do Estado na economia, incluindo o mercado de trabalho e as próprias políticas sociais, houve uma clara contrarreforma no pensamento sobre a política social, influenciada por essa concepção do mundo econômico e social.
O regime de acumulação flexível tem, dessa forma, sua própria forma de constituir e enfrentar o problema da pobreza e da superpopulação relativa. Ela se expressa na gramática de uma nova questão social e nos enfoques das capacidades e vulnerabilidades. Têm-se, portanto, novas interpretações e debates sobre a questão social e a consolidação de hegemonia do discurso liberal revisitado, ou de liberais com aspirações igualitárias, do qual o maior expoente atualmente é Amartya Sen.

\subsection{A "nova questão social"}

Com essas transformações que ocorrem com a crise do capital e as mudanças no regime de acumulação a partir da década de 1970 e as consequentes transformações na organização da produção, observou-se, como colocado por Santos (2000), o surgimento de um desemprego estrutural. Nesse cenário, noções como exclusão e vulnerabilidade social entraram em cena, visando englobar a pluridimensionalidade do fenômeno da pobreza para além do socioeconômico ou mais propriamente da renda.

Dentro de uma leitura que se tornou dominante, autores postularam que existiria uma "nova questão social" (Rosanvallon, 1998; Castel, 2000, ambos sob o pano de fundo da sociedade francesa), que se manifestaria pelo fim da sociedade salarial e a crise do Estado de Bem-Estar, tendo em vista o desemprego em massa, a precarização e as ameaças à coesão social. A pobreza, a exclusão e o desemprego não seriam residuais e conjunturais, mas permanentes e estruturais, exigindo novas formas de compreendê-los e enfrentá-los.

Para Rosanvallon, os fenômenos atuais de exclusão não remetem às categorias antigas de exploração - uma vez que a questão social do século XIX, para o autor, se referia à pauperização dos 
assalariados industriais, por conta de falta de regulação social do trabalho, e não da falta de emprego estrutural, como agora, na qual parte da população se torna excluída -, e por conta disso estaríamos presenciando uma nova questão social. O que se destaca no pensamento do autor é a ideia de que a crise é mais propriamente política, seguindo uma tradição liberal - como explicita Ahearne (2010) -, com a dissolução da solidariedade social que era gerada pelo Estado Providência, num cenário de crise fiscal do Estado, expresso no desequilíbrio entre despesas e receitas. Dessa forma, Rosanvallon (1998) compreende que o advento de uma nova questão social resulta de uma incompatibilidade entre os antigos métodos de gestão social e que, além dos problemas urgentes de financiamento e disfunção de agências do Estado, o que está posto em causa são os princípios de organização da solidariedade social - e do contrato social vigente durante o Estado Providência - e do fracasso da concepção tradicional de direitos sociais para oferecer um quadro satisfatório em que é preciso pensar a situação dos excluídos.

Um aspecto importante do pensamento de Rosanvallon, para as finalidades deste texto, é sua interpretação sobre as noções de risco e vulnerabilidade. Para o autor, na vigência do Estado Providência, com base nos seguros sociais, a noção de risco se referia a probabilidades mensuráveis de sofrer agravos de caráter conjuntural - doença, velhice, desemprego. Essa noção, frente ao agravamento do desemprego, já não seria mais útil para articular a política social. Para o autor, os riscos se tornaram coletivos e de novos tipos - catástrofes naturais e desastres tecnológicos, grandes ameaças ambientais - que afetam populações inteiras, não apenas indivíduos isolados, inviabilizando indenizações por parte do Estado, impondo limites à atuação da seguridade social (mas os anteriores persistem também: desemprego, velhice, etc.). Assim, os conceitos de precariedade ou vulnerabilidade seriam mais centrais hoje do que o de risco. Ainda, coloca que, com a mudança de escala, implica-se uma nova abordagem do vínculo social, levando a uma radicalização da perspectiva da sociedade, como uma comunidade de destino solidário.

Como aponta Alvarenga (2012), para Rosanvallon (1998), a vulnerabilidade permite perceber as especificidades dos indivíduos, sejam as inatas ou aquelas adquiridas. O reconhecimento das vulnerabilidades permitiria adequar a proteção social ao novo momento da sociedade, pois é essa noção que permite individualizar as intervenções de acordo com as demandas específicas dos cidadãos.

Como nota Leal (2004), segundo Rosanvallon, os mecanismos anteriores de solidariedade baseavam-se no sistema de seguro social, fundamentando-se a solidariedade na mutualização dos riscos sociais. A cotização entre os trabalhadores sustentava essa interpretação contratualista de solidariedade. Na visão do autor, este sistema, apoiado sobre a cidadania passiva, que associava direitos do trabalho a uma política de proteção pelo direito à vida, característica do que ele chama de Estado Providência Passivo, gerou uma crise entre a autonomia individual e a solidariedade geral. Ainda, como destaca Leal (2004), numa interpretação que parece se aproximar dos argumentos neoliberais pelo Estado mínimo, Rosanvallon diz que o "vampirismo social" minou esta solidariedade.

Para Rosanvallon, como salientam Draibe e Henrique (1988), as saídas da crise não podem ser pensadas nas alternativas entre estatização versus privatização. É necessário repensar as relações entre Estado/Sociedade. As lógicas características da estatização e da privatização devem ser substituídas por uma tríplice dinâmica articulada da socialização, da descentralização e da autonomização. 
Desta forma, o autor propõe a passagem para um Estado Providência Ativo, capaz de reconstruir o tecido social e focado na inserção pelo trabalho. Seria necessário repensar a natureza dos direitos sociais, superando a definição clássica de benefício universal sem contrapartidas. Deve-se buscar uma nova relação entre direitos e obrigações, na qual se reflete o caráter de reciprocidade entre o indivíduo e a sociedade. O "direito à inserção" seria mais complexo que o "direito social clássico", seu imperativo moral iria além do direito à subsistência, pois consideraria os indivíduos como cidadãos ativos e não apenas como assistidos. Afirmaria não apenas o "direito de viver", mas também o "direito de viver em sociedade", ligando ajuda econômica e participação social. Estabeleceria, assim, um contrato formalizando um projeto personalizado que estabelece responsabilidades recíprocas: por um lado, a obrigação da sociedade de fornecer os recursos necessários para o projeto e, por outro, a prestação de contas do beneficiário considerado ator de seu próprio futuro.

Nesse sentido, para o autor, as noções de Terceiro Setor e Economia Social ganham relevo, uma vez que nem o Estado nem o Mercado parecem ser capazes de suprir as demandas societárias do direito à inserção. Portanto, as transformações em curso, assim como as projeções possíveis, indicam a falência do modelo keynesiano de compromisso, que regula as relações entre a economia e o social. É a crise e esgotamento de um modo de regulação social, sendo parcialmente substituído por uma regulação intrassocial fundada nas relações indivíduo/sociedade ou pela forma autogestionária, que é fundada nas relações Estado/sociedade civil (Draibe \& Henrique, 1988). Torna-se evidente, assim, que o que o Estado Providência Ativo deve fazer, por meio de políticas sociais focalizadas, é contribuir para a formação de uma economia social e do terceiro setor, dando oportunidades para que os indivíduos possam empreender e acumular ativos para moldar seus próprios destinos.

Castel (1998) também irá apresentar a nova questão social como um problema de coesão social, numa perspectiva funcionalista, porém, com um enfoque no desmonte da condição salarial. Como colocam Guerra et al. (2007), a nova "questão social", para Castel, se afirma em três novas expressões: a primeira seria a desestabilização dos trabalhadores estáveis; a segunda é a instalação na precariedade, ou seja, o que deveria ser transitório tornou-se permanente, de modo que se opera um retorno às condições de precariedade próprias do século XIX, as quais haviam sido superadas pela sociedade salarial. A terceira expressão é a constituição de uma população sobrante, ou, em outras palavras, de uma população de inúteis para o mundo, no sentido da desintegração destes indivíduos, que seriam os excluídos.

A exclusão social se expressa, segundo Castel (1998), pelo fenômeno de desfiliação, de ruptura de vínculos sociais, como no caso do desemprego de longo prazo, de idosos, dependentes químicos, minorias étnicas, etc. Ela não é nem a desigualdade, nem a diferenciação social, nem a desigualdade social; a exclusão seria uma ruptura, um processo de descolagem em relação à sociedade envolvente (Rodrigues, 2000). Para Castel (1998), pode-se distinguir quatro estágios do processo de exclusão social: a integração, a vulnerabilidade, a assistência e a desfiliação. Este último corresponderia à ruptura dos laços com a própria família e os grupos mais próximos. Nessa ótica, a exclusão é o resultado de uma série de rupturas de pertenças e relações, que isola os indivíduos, afastando-os dos grupos da sociedade em geral. Segundo o autor, "hoje a zona de integração abre brechas, a zona de vulnerabilidade está em expansão e alimenta continuamente 
a zona de desfiliação" (Castel, 1991,p. 152 apud Rodrigues, 2000). A zona de vulnerabilidade seria uma zona intermediária, instável, que conjuga precariedade do trabalho e fragilidade dos suportes de proximidade (Castel, 1998).

À diferença de Rosanvallon, contudo, Castel não é incisivo nas saídas para a crise do Estado de Bem-Estar. O autor faz alguns apontamentos, indicando que a superação dessa condição exige mudanças na forma de atuação do Estado, mas não mais nem menos Estado. Este deve ser estrategista, estendendo suas intervenções para acompanhar o processo de individualização (com o fim dos coletivos típicos que geravam a identidade social da sociedade salarial) que vem ocorrendo, desarmando seus pontos de tensão e evitando rupturas, reconciliando os que caíam aquém da linha de flutuação. O Estado deve garantir um nível de proteção social para garantir a coesão social.

De todas as formas e em que pese as diferenças entre os autores e as correntes teóricas às quais são filiados, o que se observa é que o tipo de política social subjacente à resposta à crise do Estado Providência ou da sociedade salarial é uma nova forma de atuação estatal, mais individualizada e focada nos grupos mais vulnerabilizados, de forma a garantir um patamar mínimo de inserção social. Essa visão pode ser considerada regressiva em relação a uma cidadania ampliada, na qual os cidadãos são entendidos como portadores de direitos sociais que devem ser positivados por meio de políticas universais.

\subsection{A visão liberal revisitada de Amartya Sen}

Dentro do quadro teórico plural que sustenta as formas dominantes de pensar os problemas sociais, especialmente aqueles ligados às desvantagens sociais, inclui-se ainda Amartya Sen, destaque que se consolida com sua colaboração com o Banco Mundial e por ter sido agraciado com o Nobel de Economia. Sua influência nos estudos de vulnerabilidade é significativa, tanto nos que têm o foco apenas na vulnerabilidade social, como apontaremos adiante, quanto nas pesquisas focadas na vulnerabilidade socioambiental. Textos importantes nas ciências ambientais dedicadas ao tema da vulnerabilidade, como o artigo "Vulnerability", de Neil Adger (2006), e o livro do grupo coordenado por Piers Blaikie, Vulnerabilidad: el entorno social, político y economico de los desastres (1996), dão relevo a tal importância. E isso a despeito de o próprio Sen não utilizar a categoria vulnerabilidade.

Uma das relevantes contribuições de Sen é a de apontar a necessidade de pensar o desenvolvimento para além do crescimento econômico, incorporando dimensões humanas a indicadores de mensuração de desenvolvimento dos países destaca-se sua participação na equipe que formulou o Índice de Desenvolvimento Humano junto ao Banco Mundial -, e isso no coração do próprio pensamento econômico liberal.

No que tange à temática da questão social e da vulnerabilidade, as proposições de Sen que se fazem mais presentes são aquelas relativas ao debate sobre justiça social, igualdade, pobreza, intitulamentos e capacidades, que permeiam sua obra. Sen, ao discutir questões relativas ao desenvolvimento desde uma perspectiva da economia e da filosofia política, irá retomar debates caros ao liberalismo, pautando as questões relativas à igualdade e à liberdade. Sua posição poderia ser enquadrada no que Vianna (2008) chama de liberalismo revisitado e Callinicos (2009) de liberalismo igualitário. À diferença do liberalismo clássico, há um claro reconhecimento, 
nessa vertente, de incorporar questões relativas à justiça social e à igualdade.

Em Desenvolvimento como liberdade, Sen (2000) defende o corolário principal de seu pensamento - as diferentes formas de liberdade são os meios possíveis para superar a privação, a opressão, a destituição e os males que nos atingem: "a expansão da liberdade é considerada (1) o fim primordial e (2) o principal meio do desenvolvimento" (Sen, 2000, p. 52).

Essa posição de Sen é sustentada na sua abordagem das capacidades (capabilities approach, desenvolvida junto com Marta Nussbaum (Nussbaum \& Sen, 1993), e que segue sendo desenvolvida por outros pesquisadores), constituída estabelecendo um diálogo especial com o pensamento de John Rawls. Para Rawls (2003), a resolução das diferenças e dos limites existentes no interior da sociedade deveria se dar por meio de dois princípios fundamentais: assegurar um conjunto de liberdades básicas e garantir o provimento de bens sociais primários para todos. Dessa forma, os indivíduos poderiam disputar/concorrer para determinados fins em igualdade de condições.

Como aponta Dean (2009), antes da abordagem das capacidades, a teoria social da justiça de Rawls era a abordagem mais progressista dentro da perspectiva liberal, uma vez que combinava princípios negativos de liberdade com noções meritocráticas de igualdade de oportunidades e direitos positivos a bens primários. Era uma teoria, contudo, que permitia expressamente desigualdades sociais, uma vez que elas poderiam ser justificadas em termos dos benefícios que elas pudessem conferir aos menos dotados.

É justamente sobre a noção de bens primários e no foco sobre os meios que irá se centrar a crítica de Amartya Sen a John Rawls. Para Sen (1979), o equalisandum da teoria de Rawls localiza-se no es- paço avaliatório errado. Como pontua Vita (1999), Sen argumenta que a preocupação não deve ser com bens per se, mas sim com o que as pessoas, dadas certas variações interindividuais significativas, são capazes de fazer com esses bens. A métrica dos bens primários, assim como os demais enfoques normativos que fazem comparações interpessoais somente em termos da posse de determinados bens e recursos, é equivocada, segundo Sen. Para Sen, a teoria de Rawls se concentra nos "meios para a liberdade", quando o que realmente importa é a "liberdade em si mesma" (Sen, 1992) - isto é, a liberdade efetiva de escolher entre os diferentes tipos de vida que os indivíduos têm razões para valorizar. Assim, somente o foco nos funcionamentos e capacidades, em lugar de bens primários, pode captar aquilo - a "liberdade em si mesma" - que os igualitários liberais de fato prezam. Para Sen, portanto, como nota Dean (2009), as desigualdades de renda e resultado são menos importantes que a igualdade de liberdades fundamentais.

Amartya Sen define uma capacidade como a habilidade de uma pessoa realizar atos valiosos ou alcançar estágios de vida considerados valiosos por ela própria. Uma capacidade representa uma série de combinações alternativas de estados físicos e mentais que uma pessoa é capaz de fazer, de se tornar ou de ser (Sen, 1992; 1993). Portanto, as capacidades são oportunidades ou liberdades para alcançar aquilo que um indivíduo considera valioso. Assim, Sen redefiniu pobreza como uma redução objetiva nas capacidades das pessoas, em suas liberdades para escolher e agir.

As capacidades representariam o ponto de apoio essencial entre os recursos materiais e as realizações humanas. Enquanto a pobreza pode ser relativa no espaço das mercadorias, é sempre absoluta na esfera das capacidades. O argumento de Sen tem sido de que entradas iguais nem sempre 
resultam em resultados iguais porque as capacidades humanas - a liberdade real que as pessoas têm para moldar seu próprio modo de viver - podem ser objetivamente constrangidas, além de que indivíduos diferentes possuem necessidades distintas para desenvolver suas capacidades.

Como coloca Maluf (2011), a construção analítica de Sen (2000) tem, em sua base, a noção de intitulamentos (entitlements) que dependem da dotação de recursos legalmente possuídos (endowments) e da capacidade em transformá-los em bens e serviços por meio da produção, trocas e transferências. Ao tomar os intitulamentos como noção instrumental à de capacidades (capabilities), Sen coloca ênfase na capacidade de as pessoas empreenderem atividades (doings) e existências (beings) que elas têm razões para valorizar. Isto resulta em várias combinações de "modos de funcionar" (functionings) que uma pessoa pode atingir. Importa destacar que essa capacidade tem, para Sen, valor intrínseco como direito humano, além da sua função instrumental para o progresso econômico (Maluf, 2011).

Deve-se apontar que, embora as proposições de Sen sejam sedutoras e, como salienta Harvey (2005), as mais sensíveis dentro do mainstream econômico nos últimos anos, visto que ninguém será contra a ideia de que as pessoas sejam sujeitos do seu próprio destino, as bases de seu pensamento estão solidamente ancoradas no pensamento liberal e, portanto, tomam como pressupostos o ponto de vista da individualidade isolada (individualismo metodológico e ético), além de partir necessariamente da economia de mercado como melhor organizador da vida social. Ainda como destaca Harvey (2005), Sen, em Desenvolvimento como liberdade (2000), "infelizmente oculta importantes direitos sociais e políticos sob o manto das interações de livre mercado [...] sem um mercado de estilo liberal,
Sen parece dizer, nenhuma das outras liberdades parece poder funcionar" (Harvey, 2005, p. 184).

Assim, Dean (2009) pontua que as elaborações de Sen têm sido incorporadas por organismos internacionais para fomentar políticas de desenvolvimento e combate à pobreza (multidimensionalidade ou multicausalidade da pobreza) refletindo, porém, concepções que se coadunam com o programa neoliberal. O termo capital humano tem sido insinuado como sinônimo da noção de capacidades de Sen, embora o próprio autor tenha apontado o limite do uso do termo, uma vez que seres humanos não são meramente meios de produção, mas o objetivo final. Apesar de existirem usos críticos do termo, quando utilizado como uma metáfora no discurso político, o conceito de capital humano assume um significado de redutivismo econômico - indivíduos são concebidos como atuais ou potenciais atores econômicos. Seu uso reflete elementos essenciais da ortodoxia política e econômica postuladas pelo neoliberalismo (Consenso de Washington): um consenso por meio do qual a habilidade dos pobres em serem bem-sucedidos é construída como uma característica apropriada dos indivíduos (Brodie, 2007).

Essas noções levam, como ressalta Vianna (2008), a uma concepção que compete com a de Estado de Bem-Estar universal como solução conciliatória entre liberdade e igualdade. Segundo a concepção liberal revisitada, os ideais de igualdade e liberdade só podem ser compatibilizados se a igualdade é entendida como igualdade de oportunidades para que todos possam ser efetivamente livres e, assim, cidadãos autônomos por escolha própria. Como coloca Vianna (2008, p. 8), “a cidadania não pode ser produzida e distribuída como vestimenta para cobrir indivíduos desnudados pela precariedade. $\mathrm{O}$ direito a que todos têm é o direito 
de "aprender a pescar", ou seja, o direito a um ponto de partida - que é a oportunidade - igualitário".

Outro aspecto que merece destaque, abordado por Piketty (2015), é que estes princípios abstratos de justiça social são, em geral, corroborados por pensadores de diferentes espectros políticos. A principal distinção se dá na compreensão dos mecanismos que produzem a desigualdade, e os pensadores liberais, ao valorizarem a economia de livre mercado, mantêm inquestionados os mecanismos do modo de produção capitalista e a exploração da força de trabalho como fundamento do processo de acumulação e produção das desigualdades. Destaca-se ainda que, nos países centrais do capitalismo, as respostas à crise do Estado de Bem-Estar foram diversificadas e nem todos optaram por opções liberais, apesar de se registrar em sua maioria algum grau de regressividade. Como destaca Guimarães (2015), as instituições e o padrão de desenvolvimento dos Estados nacionais tiveram papel importante no padrão de reordenamento das políticas sociais.

\section{O marco da vulnerabilidade social}

São essas elaborações teóricas e políticas que se consubstanciam na noção de vulnerabilidade social, que seria uma forma de analisar desvantagens sociais para além da renda. De forma geral, pode-se dizer que se trata, sobretudo, de abordagens que visam mensurar o que indivíduos, comunidades e regiões têm ou não - seus ativos, especialmente focados na noção de capitais físico, financeiro, humano e social - que as podem caracterizar como susceptíveis à pobreza, à marginalidade, à exclusão social e aos déficits de desenvolvimento.

O trabalho seminal de Caroline Moser, amplamente citado nos estudos sobre vulnerabilidade,
"The asset vulnerability framework" (Moser, 1998) estabelece como bases teóricas para o desenvolvimento de sua abordagem, que se tornou amplamente conhecida e replicada, os trabalhos de Amartya Sen, desde seu estudo de 1981, Poverty and famines, os de Maxwell \& Smith (1993), Davies (1993), Deveraux (1993) e Putnam (1993).

De acordo com Moser (1998), o marco de vulnerabilidade dos ativos visava subsidiar políticas de redução da pobreza sustentáveis em nível local que, segundo suas palavras, "fortalecessem as soluções inventivas das próprias pessoas" e que buscassem "identificar o que as pessoas pobres têm ao invés do que elas não têm, e assim focar em seus ativos" (Moser, 1998, p. 1). Seu arcabouço serviria para desenvolver ferramentas mais apropriadas para facilitar intervenções que promovam oportunidades, bem como removam obstáculos.

A autora inicia seu artigo interessantemente relacionando que, depois de uma década de dívida e recessão, de estabilização econômica e políticas de ajustes estruturais - leia-se, reformas neoliberais - nos países em desenvolvimento e em transição, a redução da pobreza estrutural emergiu como uma prioridade central do desenvolvimento. Ela segue apontando que este interesse não apenas renovou os debates metodológicos sobre os significados e medidas da pobreza, como também desafiou os formuladores de políticas a reavaliar a viabilidade das intervenções correntes para a redução da pobreza.

De acordo com a autora, em 1990, o Banco Mundial desenvolveu uma estratégia de redução da pobreza baseada em três componentes internamente consistentes: primeiro, crescimento econômico, usando ativamente a força de trabalho dos pobres como seu ativo mais importante; segundo, investimentos em saúde e educação básicas (capital humano) para habilitar os pobres a usar sua força de trabalho produtivamente; e terceiro, a provisão de 
redes de segurança social para proteger os grupos vulneráveis e os muito pobres.

Moser segue destacando que pobreza e vulnerabilidade não são o mesmo, embora inter-relacionados. Para a autora, o primeiro é um conceito estático, fixo no tempo, enquanto vulnerabilidade seria mais dinâmico e capaz de capturar melhor os processos de mudança nos quais as pessoas se movem para dentro e para fora da pobreza. Ao longo dos anos, seu significado teria sido expandido consideravelmente para incluir uma variedade de elementos e situações de segurança dos meios de vida (livelihood security), incluindo a exposição aos riscos, aos eventos, aos choques e estresses e a dificuldade de lidar com as contingências ligadas à rede de ativos.

Assim, segundo Moser (1998), qualquer definição requer a identificação de duas dimensões da vulnerabilidade: sua sensibilidade (a magnitude da resposta de um sistema a um evento externo) e sua resiliência (a facilidade e a rapidez de um sistema em se recuperar de um stress). Estudos urbanos definem vulnerabilidade como a insegurança e a sensibilidade no bem-estar de indivíduos, domicílios e comunidades em face de um ambiente em mudança, e, implicitamente, sua responsividade e resiliência aos riscos que eles encaram durante tais mudanças negativas. As mudanças ambientais podem ser econômicas, ecológicas, sociais e políticas e podem tomar a forma de choques repentinos, tendências de longo prazo ou ciclos sazonais.

Moser liga diretamente a noção de vulnerabilidade à de capacidades. Para a autora, os trabalhadores da assistência não devem ver seus clientes como vítimas sem ajuda, pois eles possuem muitos recursos mesmo em tempos de emergência, os quais podem formar a base de sua recuperação. Os estresses e declínios econômicos podem intensificar a adversidade tanto quanto os choques repentinos ou os desastres. Nesses casos, as capacidades dos indivíduos e dos domicílios são profundamente influenciadas por fatores que vão desde perspectivas de ganhar a vida a efeitos psicológicos e sociais da privação e exclusão. Nesse sentido, seria importante reforçar as capacidades das pessoas de manejarem seus próprios destinos, mesmo em períodos de crise, de modo a reduzir sua vulnerabilidade.

Dessa forma, Moser (1998) desenvolve uma relação entre vulnerabilidade e a posse de ativos, que influenciariam na resiliência e responsividade na exploração de oportunidades e na resistência e recuperação dos efeitos negativos de um ambiente em mudança. Quanto mais ativos as pessoas tiverem, menos vulneráveis elas serão. Recorrendo a uma série de autores, identifica o que considera os principais tipos de ativos: força de trabalho; capital humano - saúde, que determina a capacidade da pessoa para trabalhar; e habilidades e educação, que determinam o retorno do trabalho; ativos produtivos; relações domiciliares - um mecanismo para agregar renda e dividir o consumo, e capital social - reciprocidade dentro da comunidade e entre os domicílios baseada na confiança que deriva dos laços sociais.

O caráter individualizante e ligado ao mercado e a redução do papel do Estado são bastante evidentes nas proposições de Moser. No quadro-síntese que apresenta, resultado de estudos de caso, destaca a vulnerabilidade em relação ao tipo de ativo, os resultados (outcomes) e as possíveis soluções. Moser aponta que, em relação ao ativo força de trabalho, o resultado da vulnerabilização é a perda de renda e a potencial solução poderia ser desenvolver esquemas de crédito por meio de organizações não governamentais para empreendimentos domiciliares. Em relação ao capital humano, a vulnerabilidade teria como resultado a inabilidade em manter investimentos em educação e saúde preventiva, para o que entre as soluções figuram providenciar créditos para 
o gasto em educação e cuidados de saúde de baixo custo e adequados. Esses exemplos mostram a índole claramente neoliberal das propostas, chanceladas pelo Banco Mundial e que perpassam a abordagem das vulnerabilidades, ao menos em suas versões mais dominantes na literatura.

Posteriormente, pesquisadores ligados à Comissão Econômica para a América Latina e o Caribe (CEPAL) avançaram e desdobraram as ideias de Moser, pontuando que, além de identificar os ativos das comunidades, era necessário estudar as estruturas de oportunidades ofertadas pelo mercado, pelo estado e pela sociedade civil, para compreender as condições de um país ou região de reagir a crises econômicas e sustentar seu desenvolvimento, gerando inclusão social. Essa literatura dos pesquisadores ligados à CEPAL tem sido amplamente utilizada nos estudos sobre vulnerabilidade no Brasil, em trabalhos como os de Marandola Jr. e Hogan (Marandola Jr. \& Hogan, 2005; 2006; Hogan \& Marandola Jr., 2005; Marandola Jr. \& Hogan, 2009) e Deschamps (2004; 2008; 2009).

Para Kaztman (2000), a ideia mais geral de vulnerabilidade remete a um estado dos domicílios que varia em relação inversa à sua capacidade de controlar as forças que modelam seu destino, ou para contrabalancear seus efeitos sobre seu bem-estar. A noção de vulnerabilidade se centra nos determinantes dessas situações, que se apresentam como resultado de uma defasagem ou assincronia entre os requerimentos de acesso à estrutura de oportunidades que brindam o mercado, o Estado e a sociedade civil, e os ativos (os capitais) dos domicílios que permitiriam aproveitar tais oportunidades. O que se observa, segundo Kaztman (2000), é que a defasagem que se produz vis-à-vis a estrutura de oportunidades do mercado deriva em um aumento de situações de precariedade e instabilidade laboral. E que a defasagem em relação à estrutura de oportu- nidades do Estado e da comunidade resulta em um aumento de situações de desproteção e insegurança. Segundo o autor, é justamente a sinergia negativa que surge do acoplamento histórico de ambos os processos que colocou em destaque os problemas de exclusão e marginalidade, cuja incorporação a um espaço tradicionalmente dominado pelos desafios da erradicação da pobreza estaria produzindo um deslocamento do eixo da questão social.

A versão dos pesquisadores da CEPAL é mais aproximada da posição de Castel (1998), uma vez que enfatiza os limites do mercado em absorver as funções do Estado e da comunidade nas estruturas de oportunidade, num cenário em que as políticas adotadas atribuem ao mercado cada vez mais centralidade na estrutura institucional da ordem social (Kaztman, 1999). Porém, como coloca Acserald (2013), mesmo os autores que consideram que a vulnerabilidade é socialmente produzida e que as práticas político-institucionais concorrem para vulnerabilizar certos grupos sociais, o locus de observação tende a ser o indivíduo.

Iamamoto (2010) chama atenção para como este conjunto de categorizações de clara inspiração liberal - riscos, ativos, vulnerabilidades, igualdade de oportunidades - implica a prevalência do mercado na oferta de oportunidades como o "trampolim para a vida segura". Seu efeito é atribuir aos indivíduos atomizados e suas famílias a responsabilidade de se protegerem quanto aos riscos (naturais e artificiais), a partir de instrumentos de manejo de riscos ofertados pelo Estado e pela iniciativa privada. Essas são expressões de uma agenda que inclui o enxugamento do Estado, além do transbordamento da linguagem e da racionalidade econômicas para o conjunto da vida social, típico do modelo de pensamento que se torna hegemônico sob o neoliberalismo (Brodie, 2007) e que funcionaliza o regime de acumulação flexível (Harvey, 2002; 2005). 
Ao mesmo tempo, destaca ainda Iamamoto (2010), tem-se a focalização das políticas e programas sociais de caráter massivo e de baixo custo nos segmentos mais pobres e vulneráveis: indivíduos, famílias, comunidades. O propósito esperado dessas iniciativas é a diminuição do risco, tendo por meta prioritária a inserção dos segmentos pobres no mercado e menos as reais necessidades sociais de que são portadores.

Nesse universo analítico, a pobreza passa a ser vista como fracasso individual no ingresso aos mecanismos de mercado, cabendo ao Estado compensar as falhas de mercado e fornecer redes de proteção social aos pobres vulneráveis para lidar com o risco, preferencialmente atribuindo à família tal responsabilidade. Ante a necessidade de reduzir gastos sociais, recomenda-se uma estratégia política que amplie o "empoderamento" dos indivíduos e reduza sua dependência perante as instituições estatais (Iamamoto, 2010). A matriz da vulnerabilidade social, dominantemente inspirada nas categorizações liberais, se torna, assim, funcional ao regime de acumulação flexível.

\section{Considerações sobre alternativas politizadoras do debate sobre vulnerabilidade}

Um dos elementos centrais para uma crítica às ideias de vulnerabilidade baseadas nos ativos/ capitais, como já apontado, é que esta se foca no déficit dos indivíduos ou, mesmo quando foca nos ativos e no que as comunidades têm, responsabiliza os indivíduos pela sua própria condição. Ainda mais, ela parte de pressupostos teóricos e políticos que não são críticos à sociedade de mercado. Não se quer dizer, com isso, que os pobres e vulneráveis são apenas vítimas das estruturas sociais que os colocam nessa condição, incapazes de agência e de assumir a responsabilidade por seus próprios destinos. Con- tudo, entende-se que tais elaborações teóricas estão mais focadas no bom funcionamento da sociedade de mercado, para o que a pobreza deve ser combatida em suas formas absolutas, do que no questionamento das estruturas sociais que produzem ativamente a pobreza, a desigualdade e a vulnerabilidade.

Para superar esses limites - aproveitando, porém, os importantes insights sobre as métricas para análise da vulnerabilidade, uma vez que a todos interessa saber quais são e quantos são os pobres e vulneráveis -, aponta-se aqui que é necessário reconhecer os limites estruturais para superação definitiva da produção da desigualdade e da vulnerabilidade na sociedade capitalista. Entende-se também que é necessário conhecer os mecanismos econômicos e políticos que produzem tais condições, de modo a politizar o debate e sustentar estratégias mais adequadas para a luta por justiça social e ambiental. Esses apontamentos sobre a necessidade de não apenas identificar e mapear a vulnerabilidade, mas compreender suas causas nas estruturas econômicas e políticas, têm sido realizados por alguns autores, como Turner II et al. (2003), Acselrad (2013; 2015), Castree et al. (2014), entre outros, especialmente dentro da literatura ambiental.

Como aponta Dean (2009), a abordagem das capacidades - e podemos estender essa crítica ao marco da vulnerabilidade, que é tributário do primeiro - permanece em silêncio sobre a questão do capitalismo em si mesmo. Ela não é e nem se propõe a ser uma teoria da mudança social. Segundo o autor, no espaço das capacidades há três grandes questões que o indivíduo não pode ver prontamente e que raramente são discutidas com clareza. Primeiro e em qualquer evento, seres humanos não podem ser livres de sua dependência de outros. Segundo Dean (2009), a forma liberal ou contratualista de compreender a natureza de nosso pertencimento à sociedade (nossa cidadania) assume o indivíduo 
como uma criatura autônoma que sobrevive pela barganha com os outros. Uma forma alternativa de ver tais coisas, mais republicana ou solidarista, seria assumir que os indivíduos são criaturas vulneráveis que sobrevivem por meio de suas relações com os outros, necessariamente em interdependência. A ordem social pode ser entendida então não apenas nos termos de como organiza os meios de produção, mas também em termos de como seus membros se cuidam e se importam uns com os outros.

Em segundo lugar, os indivíduos não são livres do controle hegemônico sobre sua participação no domínio público, uma vez que a esfera pública não é um espaço horizontal e as diferentes classes e grupos possuem capacidade assimétrica de influência. Determinar que as capacidades sejam definidas por processos públicos deliberativos, como faz Nussbaum (2000), valorizando o consenso, apaga os profundos conflitos e contradições existentes no seio da sociedade de classes, podendo apenas reproduzir, como coloca Dean (2009), os valores hegemônicos na sociedade.

Em terceiro lugar, as abordagens liberais não levam em consideração as relações capitalistas de produção, nem as consequências diretas e indiretas da exploração do trabalho humano. $\mathrm{O}$ aspecto mais central da crítica ao pensamento liberal revisitado se dá por sua adesão à economia de mercado. Dean (2009) recorre a Marx e suas proposições sobre o trabalho - a interação propositiva com o mundo a nossa volta - como a base da consciência de nossa humanidade - como espécie e social, de forma oposta à simples existência natural. O problema com o capitalismo, de acordo com Marx, é que ele transforma o trabalho em trabalho alienado, separando os seres humanos não apenas dos objetos de sua produção, mas da essência da sua humanidade social. Marx buscou expor a lógica imanente da forma mercadoria e a relação salarial sob o capitalismo.
Seu foco era na extensão da mais-valia da qual depende a acumulação de capital, que se assenta sobre a ficção do contrato livre e, por fim, na exploração do trabalho. $\mathrm{O}$ argumento de Marx é que, apesar do trabalho assalariado ser preferível à escravidão, um contrato de trabalho não pode ser totalmente livre enquanto uma parte depende da venda de sua força de trabalho para obter seus meios de subsistência.

Como destaca Netto (2007), o capítulo 23 de O Capital, "Lei geral de acumulação capitalista", revela a anatomia da questão social, sua complexidade, seu caráter de corolário (necessário) do desenvolvimento capitalista em todas as suas fases. Marx postula que a desigualdade e a pobreza não são senão o resultado dos altos níveis de acumulação e de concentração de capital, realizados a partir da apropriação do trabalho alheio, o que leva à exploração de uma classe sobre a outra.

Segundo Dean (2009), mercados para a troca de bens e serviços têm servido aos fins humanos há tempos, mas uma economia de mercado viola os requerimentos de justiça porque os indivíduos sob o capitalismo não possuem acesso igual às vantagens. Ainda mais, numa economia de mercado, funções necessárias e valiosas, como o cuidado das crianças e dos descapacitados, estudos, o voluntariado para um trabalho na comunidade, as artes amadoras, etc., não possuem nenhum valor de mercado e não são recompensados como trabalho. Nesse sentido, o capitalismo distorce nossa percepção e experiência sobre o trabalho e sobre nossa espécie. Se não limita diretamente nossas capacidades, ele as compromete, porque, em uma economia global de mercado, nossa habilidade para funcionar como nós escolhemos em algum momento irá necessariamente ser alcançada às custas da liberdade dos outros.

Dessa forma, como pontua Netto (2007), nas sociedades atuais - formações econômico-sociais fundadas na dominância do modo de produção capi- 
talista-, pobreza e desigualdade estão intimamente vinculadas: são constituintes insuprimíveis da dinâmica econômica do modo de produção capitalista a exploração, de que decorrem a desigualdade e a pobreza. No entanto, ainda segundo Netto (2007), os padrões de desigualdade e de pobreza "não são meras determinações econômicas: relacionam-se, através de mediações extremamente complexas, a determinações de natureza político-cultural"; o que se expressa por meio dos diferentes padrões de desigualdade e de pobreza vigentes nas várias formações econômico-sociais capitalistas.

Para o autor, esta determinação, que não pode desconsiderar a forma contemporânea da lei geral da acumulação capitalista, deve ter em conta a complexa totalidade dos sistemas de mediações em que esta se realiza. Dessa forma, entende-se que, mesmo dado o caráter universal e mundializado daquela lei geral, se objetivam particularidades culturais, geopolíticas e nacionais que, igualmente, requerem determinação concreta. Isto demanda a investigação das diferenças histórico-culturais (que entrelaçam elementos de relações de classe, geracionais, de gênero e de etnia, constituídos em formações sociais específicas) que se cruzam e tensionam a efetividade social.

Destaca-se, contudo, que o fato de se interpretar a insuperabilidade da questão social, da pobreza e da desigualdade sob o capitalismo, a partir de Marx, não deve redundar em imobilismo. Ao se considerar, como destacam Emel \& Peet (2001), a necessidade da tomada de decisões imediatas, é necessário fazer algo em relação às questões socioambientais, e ainda, como uma perspectiva revolucionária não está no horizonte histórico, pode-se inferir que medidas de caráter mais pragmático são necessárias.

Como pontua José Paulo Netto (2007), o que pode variar, dentro da sociedade capitalista, são os níveis e padrões de pobreza e desigualdade, e esta variação não deve ser subestimada quando estão em jogo questões que afetam a vida de bilhões de seres humanos.

Nesse sentido, Acselrad, Netto e Dean convergem para a importância de sustentar o foco nos direitos, pois a fase atual do capital, em seu regime de acumulação flexível, ao exponenciar a questão social com revigorados dispositivos de produção e reprodução de pobreza e desigualdade, "atua mediante a redução e o recorte dos direitos sociais" (Netto, 2007). Outro aspecto destacado por Acselrad (2013), bem como por Netto (2007), embora de formas distintas, diz respeito aos processos decisórios, políticos, que atribuem proteção desigual e exposição desigual aos riscos aos grupos sociais subordinados.

O reconhecimento da condição de destituídos, como aponta Acselrad (2013), é fundamental para a constituição de sujeitos coletivos, mas desde que em confronto com as obrigações públicas que lhes são devidas como direitos e que devem, em primeiro lugar, ser cobradas, ou seja, não abstraindo o papel que desempenham os mecanismos de destituição. Como explicitado por Acselrad, isto não quer dizer localizar em processos estruturais e incapturáveis a "causa" da vulnerabilidade (embora optemos por reconhecer os limites estruturais para a superação definitiva da produção da vulnerabilidade dentro do capitalismo); interessa determinar e interromper os processos decisórios que impõem riscos aos mais desprotegidos. Assim, estabelece-se a proteção aos cidadãos como responsabilidade dos Estados democráticos, em lugar de apenas mensurar os déficits nas capacidades de autodefesa dos mesmos.

A diferença entre as perspectivas liberal e histórico-crítica focada nos direitos é clara. No caso da visão que tem o foco nos indivíduos, o Estado afirmará pretender dar aos vulneráveis "defesa contra os danos", "capacidade de controlar as forças que modelam seu destino", "aumento do seu capital cul- 
tural e social", ou seja, sempre uma suplementação de uma carência, como coloca Acselrad (2013). Já numa abordagem focada nos direitos, sublinha-se algo que é devido aos cidadãos, colocando a perspectiva da problematização e da demanda de interrupção dos mecanismos de vulnerabilização, por meio da reivindicação de uma atribuição equânime de proteção e combate aos processos decisórios que impõem os riscos aos que possuem maior dificuldade de se fazer ouvir na esfera pública. Como afirma Acselrad (2013, p. 119), com este enfoque "aponta-se o processo através do qual esta capacidade de autodefesa lhes é em permanência subtraída".

Reforçando a posição pela defesa dos direitos humanos, aponta-se a leitura de Meszáros (2008) sobre o tema. Mesmo reconhecendo a natureza liberal e individual desses em sua constituição, desde a Declaração dos Direitos do Homem em 1789, o autor esclarece que estes são de interesse para aqueles que defendem a emancipação humana com base numa crítica ao capital e a necessidade de sua superação. Como afirma, enquanto estivermos onde estamos e o livre desenvolvimento das individualidades estiver tão distante como está, a realização dos direitos humanos é uma questão que permanece relevante. Assim, sob as condições da sociedade capitalista, o apelo aos direitos humanos envolve "a rejeição dos interesses particulares dominantes e a defesa da liberdade pessoal e da autorrealização individual em oposição às forças de desumanização e de reificação ou de dominação material crescentemente mais destrutivas" (Meszáros, 2008, p. 168).

\section{6. À guisa de uma conclusão}

Buscamos, ao longo do texto, mostrar o caminho que leva à adoção de forma mais geral da noção de vulnerabilidade social e seu sentido predominante, formulando que este se dá dentro do pensamento liberal revisitado e que é funcional ou funcionalizado dentro do regime de acumulação flexível. Isso diante da necessidade de aprofundar o debate no campo da pesquisa sobre vulnerabilidade socioambiental, uma vez que identificamos certa prevalência de abordagens com "afinidades eletivas", como colocam Castree et al. (2014), para o diálogo com as ciências biofísicas, especialmente as de caráter ligado ao individualismo e ao funcionalismo. Essa prevalência se mostra pelo uso dominante de autores como Amartya Sen no estudo da dimensão social da vulnerabilidade, como reconhece Adger (2006).

Por fim, e retomando a provocação inicial do artigo, apontamos que a noção de vulnerabilidade pode ser, como coloca Fussel (2007), um cluster conceitual pertinente para a pesquisa nas ciências ambientais. Porém, entende-se que é necessário, e aqui recorremos a Castree et al. (2014), que exista maior abertura para o diálogo com as ciências sociais em que o paradigma positivista não é o dominante. Além disso, é preciso que os cientistas sociais que não se sentem representados pelo atual "clima do debate" saiam de suas zonas de conforto e insiram suas perspectivas de forma mais consistente nos espaços das ciências ambientais. Enriquecer o ambiente intelectual do debate nesse campo é tarefa imprescindível para que se possa enfrentar os imensos problemas socioambientais colocados diante de nós.

\section{Agradecimentos}

A pesquisa que deu origem a esse artigo teve apoio financeiro da Fundação Araucária e da Capes, fundamentais para sua realização. 


\section{Referências}

Acselrad, H. O conhecimento do ambiente e o ambiente do conhecimento: anotações sobre a conjuntura do debate sobre vulnerabilidade. Em Pauta, 11(32), 115-129, 2013.

Acselrad, H. Vulnerabilidade social, conflitos ambientais e questão urbana. O Social em Questão, ano XVIII, 33, 57-68, 2015.

Acselrad, H.; Mello, C. C. A.; Bezerra, G. N. O que é justiça ambiental? Rio de Janeiro: Garamond, 2009.

Adger, W. N. Vulnerability. Global Environmental Change, 16, p. 268-281, 2006.

Ahearne, J. Intellectuals, culture and public policy in France: approaches from de left. Londres: Liverpool University Press, 2010.

Alvarenga, M. S. Risco e vulnerabilidade: razões e implicações para o uso na Política Nacional de Assistência. Vitória, Dissertação (Mestrado em Política Social) - Universidade Federal do Espírito Santo, Centro de Ciências Jurídicas e Econômicas, 2012.

Alves, H. P. Metodologias de integração de dados sociodemográficos e ambientais para análise de vulnerabilidade socioambiental em áreas urbanas no contexto das mudanças climáticas, In: Hogan, D. J.; Marandola, E. (Orgs.). População e mudança climática: dimensões humanas das mudanças ambientais globais. Campinas: NEPO/Unicamp; Brasília: UNFPA, 2006. p.75-105.

Alwang, J.; Siegel, P. B.; Jørgensen, S. L.Vulnerability: A View From Different Disciplines. Social Protection Discussion Paper Series, 0115. Social Protection Unit, Human Development Network, The World Bank, jun./2011.

Antunes, R. Adeus ao trabalho? Ensaio sobre as metamorfoses e a centralidade do mundo do trabalho. 6. ed. São Paulo: Cortez, 1998.

Antunes, R. Os sentidos do trabalho. 6. ed. São Paulo: Boitempo Editorial, 2002.

Behring, E. R.; Boschetti, I. Política social: fundamentos e história. 3. ed. São Paulo: Cortez, 2009.

Blaikie, P.; Cannon, T.; David, I.; Wisner, B. (Orgs.). Vulnerabilidad: el entorno social, politico y economico de los desastres. Colombia: La Red, 1996.
Brodie, J. Reforming social justice in neoliberal times. Studies in Social Justice, 1(2), 2007.

Callinicos, A. Igualitarismo e crítica social. Lutas Sociais, São Paulo, 21/22, 2009.

Castel, R. De l'indigence à l'exclusion, la desaffiliation. In: Donzelot, J. Face à exclusion, le modelo français. Paris: Esprit, 1991.

Castel, R. Metamorfoses da questão social. Petrópolis, RJ: Vozes, 1998.

Castel, R. As armadilhas da exclusão. In: Belfiore-Wanderley, M.; Bógus, L.; Yazbek, M.C. (Orgs.). Desigualdade e a questão social. 2. ed. São Paulo: EUC, 2000. p. 17-49.

Castree, N.. Changing the intellectual climate. Nature Climate Change, 4, 763-768, set. 2014.

Cutter, S. L. A ciência da vulnerabilidade: modelos, métodos e indicadores. Revista Crítica de Ciências Sociais, 93, 59-69, 2011.

Cutter, S. L.; Emrich, C. T.; Webb, J. J.; Morath, D. Social Vulnerability to Climate Variability Hazards: A Review of the Literature. Oxfam America, June/2009.

Davies, S. Are coping strategies a cop out? IDS Bulletin, 24(4), 60-72, 1993.

Dean, H. Critiquing capabilities: the distractions of a beguiling concept. Critical Social Policy, 29(2), 261-273, 2009.

Deschamps, M. V. Vulnerabilidade socioambiental na Região Metropolitana de Curitiba. Curitiba, Tese (Doutorado em Meio Ambiente e Desenvolvimento) - Universidade Federal do Paraná, 2004.

Deschamps, M. V. Estudo sobre a vulnerabilidade socioambiental na Região Metropolitana de Curitiba. Cadernos Metrópole, 9, 191-219, 2008.

Deschamps, M. V. (Org.). Vulnerabilidade socioambiental das regiões metropolitanas brasileiras. Rio de Janeiro: Letra Capital, 2009.

Devereaux, S. Goats before ploughs: dilemmas of household response sequencing during food shortage. IDS Bulletin, 24(4), 52-59, 1993. 
Draibe, S.; Henrique, W. "Welfare State", crise e gestão da crise: um balanço da literatura internacional. Revista Brasileira de Ciências Sociais, 3(6), 1988.

Emel, J.; Peet, R.. Resource management and natural hazards. In: Peet, R.; Thrift, N. New models in geography. v. 1, 2. ed. London: Routledge, 2001. 2001.

Friedman, M. Capitalismo e liberdade. Rio de Janeiro: Artenova, 1977.

Fussel, H.M.. Vulnerability: A generally applicable conceptual framework for climate change research. Global Environmental Change, n.17, p.155-167, 2007.

Guerra, Y.; Ortiz, F. S. G.; Valente, J.; Fialho, N. O debate contemporâneo da "questão social". In: Anais da III Jornada Internacional de Politicas Públicas, São Luís - MA, 28 a 30 de agosto 2007 .

Guimarães, A. Q. Economia, instituições e estado de bem-estar social: respostas à nova configuração do capitalismo pós-1970. Dados, Rio de Janeiro, 58(3), 617-650, set. 2015.

Harvey, D. A condição pós-moderna. São Paulo: Loyola, 2002.

Harvey, D. A brief history of neoliberalism. New York: Oxford University Press, 2005.

Hayek, F. V. Os fundamentos da liberdade. Brasília: Editora Universidade de Brasília, 1983.

Hogan, D. J.; Marandola Jr., E. Towards an interdisciplinary conceptualisation of vulnerability. Population, Space and Place, 11(6), 455-471, 2005.

Iamamoto, M. V. Serviço social em tempo de capital fetiche: capital financeiro, trabalho e questão social. São Paulo: Cortez, 2010.

Kaztman, R.. Activos y estructura de oportunidades. Estudios sobre las raíces de la vulnerabilidad social en Uruguay. Uruguay: PNUD-Uruguay e CEPAL-Oficina de Montevideo, 1999.

Kaztman, R. Notas sobre la medición de la vulnerabilidad social. México: BID-BIRF-CEPAL, 2000. (Borrador para discusión. 5 Taller regional, la medición de la pobreza, métodos e aplicaciones).

Leal, G. F. A noção de exclusão social em debate: aplicabilidade e implicações para a intervenção prática. Trabalho apresentado no XIV Encontro Nacional de Estudos Populacionais, ABEP, realizado em Caxambú-MG - Brasil, de 20-24 de Setembro de 2004.

Lipietz, A. New tendencies in the international division of labour: regimes of accumulation and modes of regulation. In: Scott, A.; Storper, M. (Eds.). Production, Work, Territory: the geographical anatomy of industrial capitalism. London/Boston: Allen \& Unwin, 1986.

Maluf, R. S. Mudanças climáticas, desigualdades sociais e populações vulneráveis no Brasil: construindo capacidades. Relatório de pesquisa. Rio de Janeiro, maio/2011.

Marandola Jr., E.; Hogan, D. J. Vulnerabilidades e riscos: entre Geografia e Demografia. Revista Brasileira de Estudos de População, 22(1), 29-53, 2005.

Marandola Jr., E.; Hogan, D. J. As dimensões da vulnerabilidade. São Paulo em Perspectiva, 20, 33-43, 2006.

Marandola Jr., E.; Hogan, D. J. A vulnerabilidade do lugar vs. vulnerabilidade sociodemográfica: implicações metodológicas de uma velha questão. Revista Brasileira de Estudos de População, v.26, n.2, p.161-181, jul/dez 2009.

Marx, K. O capital: crítica da economia política. Livro I: O processo de produção do capital. São Paulo: Boitempo, 2013.

Maxwell, M.; Smith, M. Household food security: a conceptual review. In: Maxwell, S.; Frankenberger, T. (Eds.). Household Food Security: Concepts, Indicators, Measurements: A Technical Review. UNICEF/IFAD, 1993.

Meszáros, I. Filosofia, ideologia e ciência social. São Paulo: Boitempo Editorial, 2008.

Meszáros, I. Estrutura social e formas de consciência: a determinação social do método. São Paulo: Boitempo Editorial, 2009.

Montaño, C. Pobreza, "questão social” e seu enfrentamento. Revista Serviço Social \& Sociedade, 110, 270-287, 2012.

Moser, C.. The asset vulnerability framework: reassessing urban poverty reduction strategies. World Development, 26(1), 1-19, 1998.

Netto, J. P. Cinco notas a propósito de la "cuestión social". In: Borgianni, E.; Guerra, Y.; Montaño, C. Servicio social crítico: hacia la construcción del Nuevo Proyecto ético-político profesional. São Paulo: Cortez, 2003. 
Netto, J. P. Desigualdade, pobreza e serviço social. Em Pauta, Rio de Janeiro, 19, 135-170, 2007.

Netto, J. P. Crise do capital e consequências societárias. Serviço Social e Sociedade, 111, 413-429, 2012.

Nozick, R. Anarquia, Estado e utopia. Rio de Janeiro: Jorge Zahar Editora, 1991.

Nussbaum, M. Women and Human Development: The capabilities approach. Cambridge: Cambridge University Press, 2000.

Nussbaum, M.; Sen, A. The quality of life. Oxford: Clarendon Press, 1993.

O’Brien, K.; Eriksen, S.; Schjolden, A.; Nygaard, L. What's in a word? Conflicting interpretations of vulnerability in climate change research. CICERO Working Paper n. 4. Norway, 2004.

Piketty, T. A economia da desigualdade. Rio de Janeiro: Intrínseca, 2015.

Porto, M.F.S.. Complexidade, processos de vulnerabilização e justiça ambiental: um ensaio de epistemologia política. Revista crítica de ciências sociais, 93, junho 2011, p. 31-58.

Putnam, R. Making democracy work: civic tradition in modern Italy. Princeton: Princeton University Press, 1993.

Rawls, J. Justiça como equidade: uma reformulação. São Paulo: Martins Fontes, 2003.

Rodrigues, E. V. O Estado-providência e os processos da exclusão social: considerações teóricas e estatísticas em torno do caso português. Revista da Faculdade de Le- tras: Sociologia, 10, 173, 2000. Disponível em: <https:// repositorio-aberto.up.pt/handle/10216/8982>.

Rosanvallon, P. A nova questão social: repensando o Estado Providência. Brasília: Instituto Teotônio Vilela, 1998.

Rostow, W. W. As etapas do desenvolvimento econômico. Rio de Janeiro: Zahar, 1961.

Santos, M. Por uma outra globalização: do pensamento único à consciência universal. Rio de Janeiro: Record, 2000.

Sen, A. Equality of what? The Tanner Lectures on Human Values. Stanford University, 1979. Disponível em: <http:// tannerlectures.utah.edu/_documents/a-to-z/s/sen80.pdf $>$.

Sen, A. Poverty and famines. Oxford: Oxford University Press, 1981.

Sen, A. Inequality reexamined. Cambridge, Mass.: Harvard University Press, 1992.

Sen, A. O desenvolvimento como expansão de capacidades. Lua Nova, 28/29, 313-333, 1993.

Sen, A. Desenvolvimento como liberdade. São Paulo: Companhia das Letras, 2000.

Turner II, B. L. et al. A framework for vulnerability analysis insustainability science. PNAS, 100(14), jul./2003.

Vianna, M. L. T. W. A nova política social no Brasil: uma prática acima de qualquer suspeita teórica? Praia Vermelha, 18, 120-144, 2008.

Vita, Á. de. Justiça distributiva: a crítica de Sen a Rawls. Dados, 42(3), 471-496, 1999. 